\title{
DEVELOPMENT OF ELECTROCHEMICAL METHODS FOR PRODUCTION OF PURE THALLIUM
}

\author{
YENLIK ZH. USSIPBEKOVA ${ }^{a}$, GULZIYA A. SEILKHANOVA ${ }^{\mathrm{a} *}$, \\ ANDREY V. BEREZOVSKIYa, ANDREY P. KURBATOV ${ }^{a}$, \\ MICHAEL K. NAURYZBAEV ${ }^{\mathrm{a}}$
}

\begin{abstract}
In this work, the electrochemical studies were carried out to improve the purity of rough thallium. The results were obtained by the rough thallium refining through the anodic deposition of thallium oxide (TI2O3), followed by its reduction to TI+ by hydroxylamine and repeated electrolysis. At the same time, platinum anode material was replaced with glassy carbon material to reduce economic costs in production. It was found that the addition of ammonium thiocyanate after the dissolution of thallium oxide(III) in nitric acid promotes the inhibition of re-formation of thallium oxide at the anode, as well as more complete oxidation of trivalent thallium to a monovalent state. The thallium obtained in this way is characterized by a purity of $99.96 \%$. Based on the obtained experimental data the principal schemes for obtaining pure thallium are proposed.
\end{abstract}

Keywords: thallium, glassy carbon, discharge ionization, refining, thallium oxide, reduction, polarity reversal, electrolysis.

\section{INTRODUCTION}

Currently, the successful development of many branches of chemical, metallurgical, instrument-making, space fields is directly related to the use of new materials based on rare elements with specific application characteristics. Due to its physical and chemical characteristics, in particular, thallium, as well as its compounds of high purity, are widely used in many areas of science and technology. It is known that alloys containing thallium have high wear resistance, inertness with respect to acids, fusibility [1-5]. Thallium

\footnotetext{
a Al-Farabi Kazakh National University, Faculty of Chemstry and Chemical Technology, 71 AlFarabi av., 050040 Almaty, Kazakhstan

${ }^{*}$ Corresponding author: g_seilkhanova@mail.ru
} 
compounds are widely used in optical and radiation engineering [6-8]. Thallium and its compounds are very toxic $[9,10]$. However, the toxicity of thallium is not a fundamental reason to refuse to use it. Nevertheless, pyrometallurgical methods, where high temperatures and pressures are applied, fade into the background in the age of development of hydrometallurgy. There are various methods for refining thallium. These include amalgam methods, vacuum distillation, zone recrystallization, electrolysis [2]. The amalgam method makes it possible to obtain high-purity thallium from dilute solutions after decomposition of thallium concentrates. The disadvantage of this method is the use of a toxic metal - mercury. The methods of vacuum distillation and zone recrystallization are characterized by a complex technological implementation of the process of obtaining a pure metal. Studies have shown that thallium is successfully purified by zone recrystallization and by drawing out from the melt of the impurities of copper, aluminum, zinc, cadmium, mercury, cobalt and magnesium [11]. However, there is no effect of purification of thallium by crystallization methods from lead impurities. In this regard, electrolysis as a method of refining is one of the best methods for producing high-purity metals [12]. It is characterized by the simplicity of instrumentation, the ability to effectively conduct processes at normal temperatures and pressures, and high performance. In [13-17] the authors demonstrated the fundamental possibility of electrochemical thallium refining through the stage of production of thallium oxide (III).

In this regard, research in the field of electrochemical methods for producing high purity thallium has particular relevance.

This paper presents the results of the development of methods for producing pure thallium, which can be used to optimize the technology of refining rough thallium. The object of the study was the model solution of the following composition: $95 \%$ - TI, $2.5 \%-\mathrm{Pb}, 0.75 \%-\mathrm{Cu}, 1.5 \%-\mathrm{Cd}, 0.25 \%-$ $\mathrm{Fe}$. This composition corresponds to $95 \%$ rough thallium.

\section{RESULTS AND DISCUSSION}

In order to obtain pure thallium, the polarization curves of thallium sulfate $\left(\mathrm{Tl}_{2} \mathrm{SO}_{4}\right)$ were recorded, and the thallium recovery potential was found. Previously, it was investigated that the maximum conditional current efficiency of thallium is typical for sulfate solution than nitrate and acetate, due to the lower contribution of adverse reactions. Sulfate electrolyte was chosen for this purpose [18]. 
As can be seen from Figure 1, a wave at a potential of $-0.85 \mathrm{~V}$ is observed in the sulfate electrolyte on the polarization curve in the cathode region, which corresponds to the process of thallium reduction $\left(\mathrm{TI}^{+}+1 \mathrm{e}^{-} \rightarrow \mathrm{TI}^{0}\right)$, and then hydrogen is released. On the reverse course of the polarization curve, an anode peak is observed at a potential of $-0.7 \mathrm{~V}$, which corresponds to the dissolution of the precipitated thallium $\left(\mathrm{Tl}^{0} \rightarrow \mathrm{Tl}^{+}+1 \mathrm{e}^{-}\right)$.

Table 1. The conditional current efficiency at different sweep rates

\begin{tabular}{|l|c|c|}
\hline Electrode & $v[\mathrm{mV} / \mathrm{s}]$ & Output current, \% \\
\hline Glass carbon & 50 & $60.0 \pm 3.3$ \\
\cline { 2 - 3 } & 20 & $83.0 \pm 3.7$ \\
\cline { 2 - 3 } & 10 & $59.0 \pm 2.9$ \\
\cline { 2 - 3 } & 5 & $58.0 \pm 2.6$ \\
\hline
\end{tabular}

The conditional current efficiency at different sweep rates was also calculated during the study. The results showed that $20 \mathrm{mV} / \mathrm{s}$ is an optimal rate (Table 1). At a sweep rate of $50 \mathrm{mV} / \mathrm{s}$ thallium ions cannot settle on the cathode due to the high speed, hence, the dissolution at the anode is less. At low sweep rates other side reactions can occur along with thallium deposition, therefore the current is not completely consumed for thallium reduction. Based on the results obtained, a sweep rate of $20 \mathrm{mV} / \mathrm{s}$ was chosen for further research.

In order to optimize the process of purification of rough thallium, studies were carried out in a bulk electrolysis cell at a potential of $-0.85 \mathrm{~V}$, in which a glassy carbon plate was used as the cathode, platinum served as the anode, the reference electrode was silver chloride electrode. It has been established that in addition to deposition on the cathode of thallium $\left(\mathrm{Tl}^{+}+1 \mathrm{e}^{-} \rightarrow \mathrm{Tl}^{0}\right)$, at the anode at $\mathrm{pH}>2$, the platinum plate is covered with a dark brown precipitate, which is the trivalent thallium oxide $\left(\mathrm{Tl}_{2} \mathrm{O}_{3}\right)$ according to the literature $[19,20]$. In this case, the following reaction takes place at the anode:

$$
2 \mathrm{TI}^{+}+3 \mathrm{H}_{2} \mathrm{O}=\mathrm{TI}_{2} \mathrm{O}_{3}+6 \mathrm{H}^{+}+4 \mathrm{e}^{-}
$$




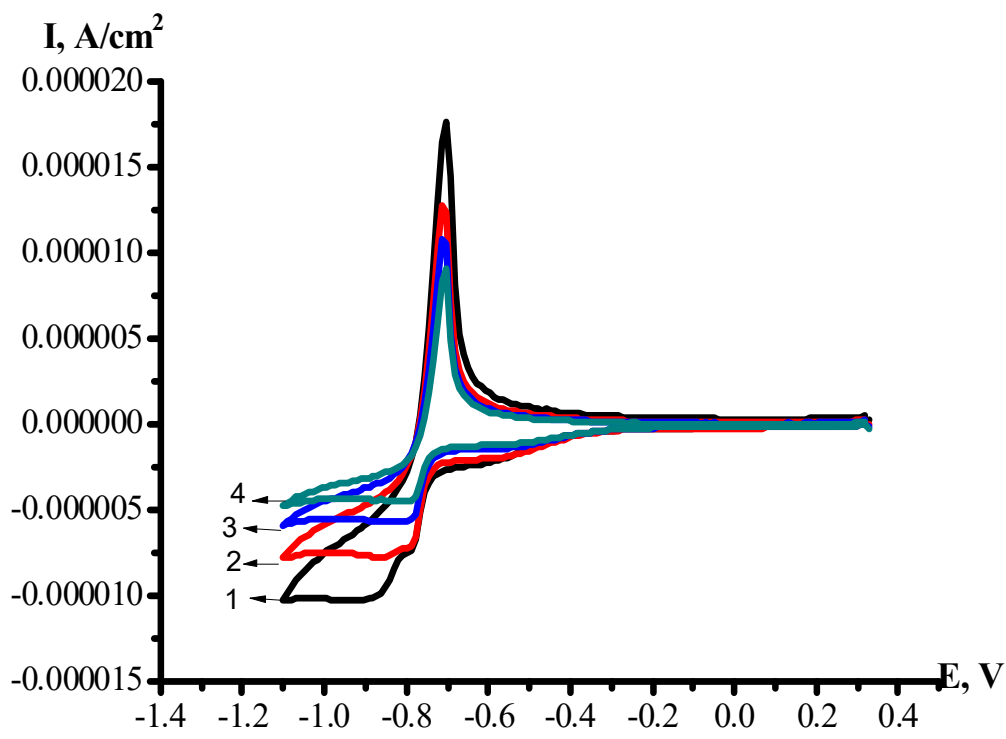

Figure 1. Polarization curves of $\mathrm{Tl}_{2} \mathrm{SO}_{4}$ on glassy carbon electrode at different scan rates, Experimental conditions: electrolyte, $10^{-3} \mathrm{~mol} \mathrm{~L}^{-1} \mathrm{Tl}_{2} \mathrm{SO}_{4}$; scan rates, 1-50, 2- 20, 3- 10, 4- 5mV/s; starting potential $0.3 \mathrm{~V}, \mathrm{pH}=2$

The fact of the anodic formation of $\mathrm{Tl}_{2} \mathrm{O}_{3}$ in the work was used for the selective deposition of thallium from the model solution of the following composition: $95 \%$ - Tl, $2.5 \%$ - Pb, $0.75 \%$ - $\mathrm{Cu}, 1.5 \%$ - Cd, $0.25 \%$ - Fe (this composition corresponds to $95 \%$ rough thallium). The results of qualitative and quantitative analysis of impurities of cathode and anode sediments obtained by atomic emission spectroscopy are presented in table 1. As can be seen from this table, almost complete deposition of lead ions in the form of $\mathrm{PbSO}_{4}$ occurs after contact with sulfuric acid with a model solution. At the same time, high content of other impurities (copper, cadmium, iron) is observed in the cathode precipitate, due to close or more positive electrode potentials.

Influence of $\mathrm{pH}$. The most pure, i.e. with a smaller amount of these impurities is the anodic precipitate $-\mathrm{Tl}_{2} \mathrm{O}_{3}$. It should be noted that its most dangerous impurity is an admixture of iron, which co-precipitates with thallium oxide, due to the close $\mathrm{pH}$ values of hydrate formation [21]. After electrolysis, $\mathrm{Tl}_{2} \mathrm{O}_{3}$ is formed at the anode (at $\mathrm{pH}=5$, the degree of purity of the oxide is $99.60 \%$ ), then this oxide was dissolved in concentrated nitric acid. Then, thallium (III) was reduced by hydroxylamine to the monovalent state: 


$$
2 \mathrm{Tl}^{3+}+2 \mathrm{NH}_{2} \mathrm{OH}=2 \mathrm{TI}^{+}+\mathrm{N}_{2} \mathrm{O}+\mathrm{H}_{2} \mathrm{O}+4 \mathrm{H}^{+}
$$

Further, repeated electrolytic cathode emission of thallium on glassy carbon at $\mathrm{pH}=2$ was carried out. As can be seen from table 2, the degree of purity of thallium was $99.73 \%$.

Also, an attempt was made to obtain pure thallium by replacing the polarity. In this case, the platinum plate on which the thallium oxide is deposited becomes the cathode and repeated electrolysis was carried out at $\mathrm{pH}=11$. At the second stage of electrolysis, pure platinum was used as the anode. The electrolysis was carried out at a potential of $-0.85 \mathrm{~V}$ for 30 minutes. During repeated electrolysis, thallium reduction directly from $\mathrm{Tl}_{2} \mathrm{O}_{3}$ was observed. At lower $\mathrm{pH}$ values, reduction to metallic thallium is complicated by the side reaction of hydrogen evolution, since the overvoltage of hydrogen on platinum is low. As can be seen from table 1, in this case, the purity of the precipitated thallium is $99.81 \%$. This method has the potential for implementation in production, since it is less time-consuming, however it is necessary to develop optimal conditions for increasing the purity of thallium.

Table 2. The content of impurities in the anode and cathode sediments.

\begin{tabular}{|l|l|l|c|c|c|}
\hline $\begin{array}{c}\text { Electrode, } \\
\mathrm{pH}\end{array}$ & $\begin{array}{c}\text { Content of } \\
\mathrm{Tl}, \%\end{array}$ & $\begin{array}{c}\text { Content of } \\
\mathrm{Cd}, \%\end{array}$ & $\begin{array}{c}\text { Content of } \\
\mathrm{Cu}, \%\end{array}$ & $\begin{array}{c}\text { Content of } \\
\mathrm{Fe}, \%\end{array}$ & $\begin{array}{c}\text { Content of } \\
\mathrm{Pb}, \%\end{array}$ \\
\hline $\begin{array}{l}\text { before } \\
\text { electrolysis }\end{array}$ & $95.00 \pm 0.07$ & $1.50 \pm 0.05$ & $0.75 \pm 0.02$ & $0.25 \pm 0.01$ & $2.50 \pm 0.08$ \\
\hline $\begin{array}{l}\text { Cathode } \\
(\mathrm{GC}), \mathrm{pH}=2\end{array}$ & $97.40 \pm 0.09$ & $0.93 \pm 0.01$ & $1.50 \pm 0.05$ & $0.17 \pm 0.01$ & 0 \\
\hline $\begin{array}{l}\mathrm{Cathode}, \\
\mathrm{pH}=5\end{array}$ & $98.70 \pm 0.08$ & $0.72 \pm 0.06$ & $0.45 \pm 0.02$ & $0.13 \pm 0.01$ & \\
\hline $\begin{array}{l}\text { Anode, } \mathrm{pH}=5 \\
\text { (degree of } \\
\left.\text { purity } \mathrm{Tl}_{2} \mathrm{O}_{3}\right)\end{array}$ & $99.60 \pm 0.09$ & $0.03 \pm 0.01$ & $0.07 \pm 0.01$ & $0.30 \pm 0.02$ & 0 \\
\hline $\begin{array}{l}\text { Cathode } \\
\text { (GC), } \mathrm{pH}=1 \\
\text { after } \\
\text { reduction } \\
\text { with } \\
\text { hydroxylamin } \\
\text { e (from } \\
\text { T/2O3) }\end{array}$ & $99.73 \pm 0.01$ & $0.02 \pm 0.002$ & 0 & $0.26 \pm 0.01$ & 0 \\
\hline $\begin{array}{l}\text { Cathode } \\
\text { (GC), after } \\
\text { replacing } \\
\text { polarity }\end{array}$ & $99.81 \pm 0.003$ & $0.03 \pm 0.001$ & $0.006 \pm 0.001$ & $0.10 \pm 0.02$ & 0 \\
\hline
\end{tabular}


Based on the analysis of experimental data, the following schemes for obtaining pure thallium are proposed, which are presented in Figures 2-3. In the proposed schemes, the production of pure thallium is carried out by repeated electrolysis of the solution obtained by dissolving the anode precipitate $\mathrm{Tl}_{2} \mathrm{O}_{3}$.

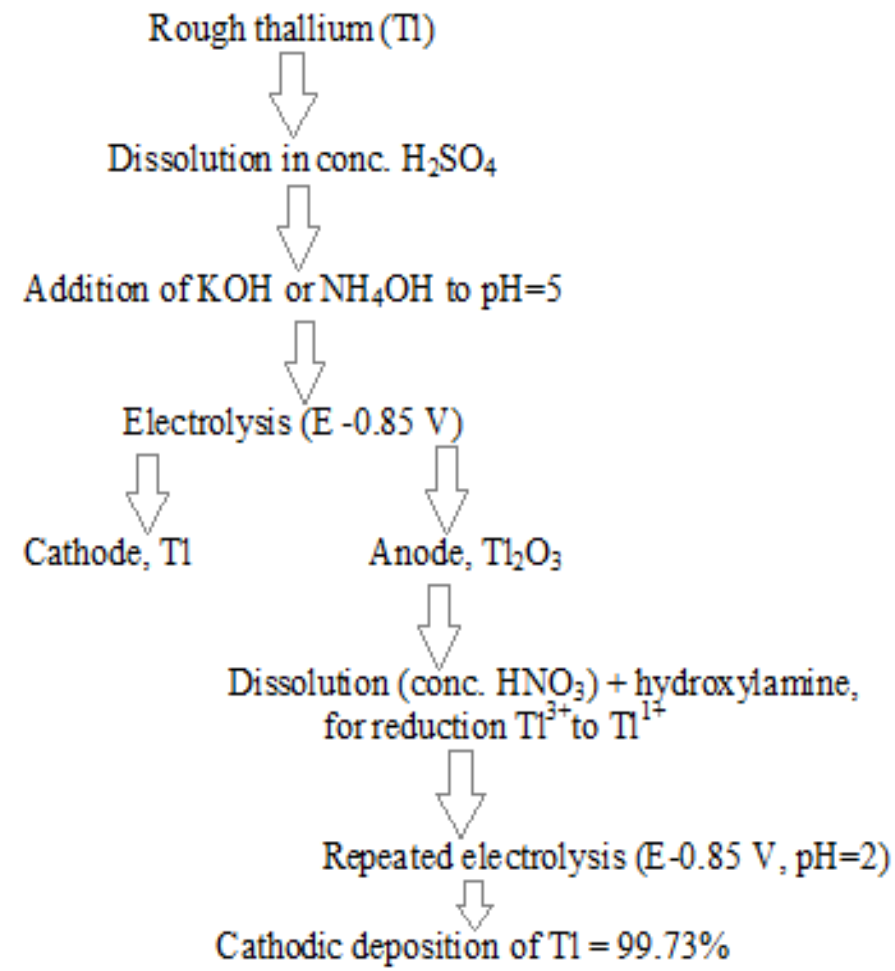

Figure 2. The scheme for obtaining pure thallium using hydroxylamine 


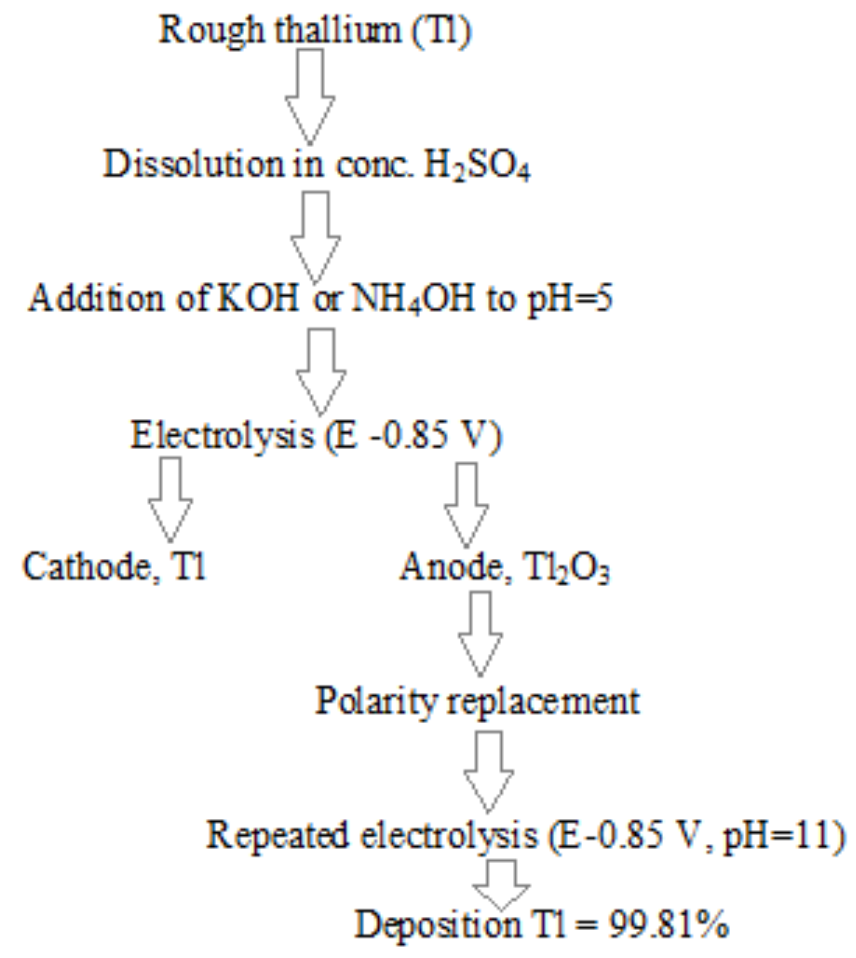

Figure 3. The scheme for obtaining pure thallium by replacing the polarity

The influence of reducing agent. Based on the results of quantitative analysis, it was established that the main impurity, which is found in thallium oxide (III), is an iron impurity. $10 \mathrm{ml}$ of $10^{-2} \mathrm{~mol} \mathrm{~L}^{-1}$ solution of ammonium thiocyanate $\left(\mathrm{NH}_{4} \mathrm{SCN}\right)$ was added to bind iron ions to the electrolyte formed by dissolution of thallium oxide (III) in nitric acid. It is known that this results in the formation of the iron thiocyanate complex [22]:

$$
\mathrm{Fe}^{3+}+3 \mathrm{SCN}^{-}=\mathrm{Fe}(\mathrm{SCN})_{3}
$$

It was found that the addition of thiocyanate also contributes to the inhibition of the process of re-formation of thallium oxide. It should be noted that after the dissolution of thallium oxide (III) in nitric acid, repeated electrolysis to produce metallic thallium should be carried out at $\mathrm{pH}=1-2$. 
Since at higher $\mathrm{pH}$ values $\mathrm{Tl}_{2} \mathrm{O}_{3}$ is precipitated, the formation of which is undesirable at this stage. And at low $\mathrm{pH}$ values, the formation of metallic thallium at the cathode is complicated by the parallel hydrogen release. Therefore, for electrolysis at higher $\mathrm{pH}$ values, it is necessary to introduce an additive into the electrolyte, which will inhibit the re-formation of $\mathrm{Tl}_{2} \mathrm{O}_{3}$ at the anode. For this purpose, as well as a complexing agent, a low molecular weight ligand of ammonium thiocyanate was added to the electrolyte. As a result of the addition of ammonium thiocyanate, in addition to iron thiocyanate, thallium (I) thiocyanate is formed, which is soluble in water [21]:

$$
3 \mathrm{Tl}^{3+}+4 \mathrm{SCN}^{-}+4 \mathrm{H}_{2} \mathrm{O}=3 \mathrm{TI}^{+} \mathrm{SCN}^{-}+\mathrm{HCN}+7 \mathrm{H}^{+}+\mathrm{SO}_{4}{ }^{2-}
$$

This allows thallium to be converted from oxidation state $(+3)$ to thallium (+1), which also eliminates the possibility of re-formation of $\mathrm{Tl}_{2} \mathrm{O}_{3}$.

Figures 4 ( $a$ and $b$ ) show the cyclic voltamogramms of thallium without the addition of ammonium thiocyanate (a), with the addition of thiocyanate (b). In Figure 4a, in the anode part, two peaks are clearly visible: the peak at $-0.6 \mathrm{~V}\left(\mathrm{TI}^{0} \rightarrow \mathrm{TI}^{+}+1 \mathrm{e}^{-}\right)$corresponds to the dissolution of metallic thallium, and the peak at $-0.48 \mathrm{~V}\left(\mathrm{TI}^{+} \rightarrow \mathrm{Tl}^{3+}+2 \mathrm{e}^{-}\right)$- to the oxidation of monovalent thallium to trivalent. Figure $4 \mathrm{~b}$ shows one peak at $-0.6 \mathrm{~V}\left(\mathrm{TI}^{0} \rightarrow\right.$ $\mathrm{Tl}^{+}+1 \mathrm{e}^{-}$) corresponding to the dissolution of metallic thallium. The obtained experimental data prove that, with the addition of ammonium thiocyanate, trivalent thallium is absent in the solution, i.e. it is completely reduced to its oxidation state $(+1)$.

When metal thallium is obtained, dendrites are formed at the cathode, which reduces in this place the distance between the cathode and the anode. The decrease of the interelectrode distance leads to a decrease in electrical resistance, and, consequently, to a local increase in current density [23]. The latter causes the accelerated deposition of thallium on the dendrite and its accelerated growth. Dendrite growth can eventually lead to a short circuit between the cathode and the anode. In the presence of dendrites, a highly developed cathode surface holds a large amount of electrolyte and is poorly washed, that worsens the quality of the target product, and also reduces the purity of thallium.

To improve the cathode surface, various surface-active additives are introduced into the electrolytes: glue (wood), gelatin, etc. [24]. One explanation of the mechanism of surfactants is that they are adsorbed on the most active parts of the surface, and at the same time induce a local increase in electrical resistance, which prevents the growth of dendrite, as a result, the surface becomes smoother, and the cathodic precipitate more dense. After the cathode surface is aligned, the colloidal particle is desorbed into the electrolyte. 
Solutions of additives are introduced into the circulating electrolyte. Usually glue and gelatin are introduced together. It is known from the literature that $20 \mathrm{~g}$ of glue and $40 \mathrm{~g}$ of gelatin are usually injected per ton of produced metal [25].

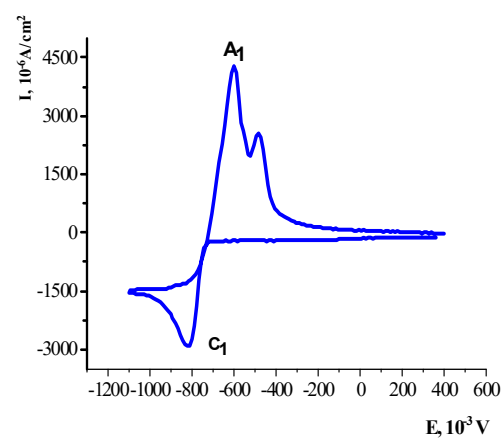

a)

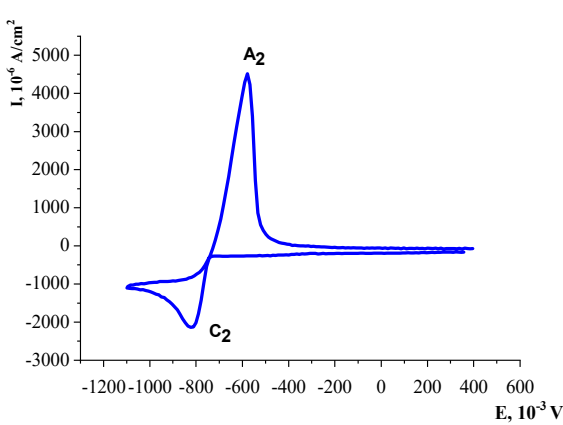

b)

Figure 4. Polarization curves of $10^{-2} \mathrm{~mol} \mathrm{~L}^{-1} \mathrm{Tl}_{2} \mathrm{SO}_{4}$ on glassy carbon electrode without (a) and with the addition of $10^{-2} \mathrm{~mol} \mathrm{~L}^{-1}$ ammonium thiocyanate (b).

Experimental conditions: scan rate, $20 \mathrm{mV}^{*} \mathrm{~s}-1$; starting potential $0.3 \mathrm{~V}, \mathrm{pH}=2$

In this work, $10 \mathrm{ml}$ of a solution containing $0.0001 \mathrm{~g}$ of wood glue and $0.0002 \mathrm{~g}$ of gelatin were added to the electrolyte to obtain pure thallium. In this case, a homogeneous cathodic precipitate of thallium was obtained, the purity of which is not deteriorated in comparison with thallium obtained without these additives. In the case of thallium without surfactant additives, it is a spongy mass poorly kept on the cathode. As it is known, continuous mixing of the solution is required to intensify the adsorption of surfactants on the electrode [26]. For these purposes, a magnetic stirrer was used, and the effect of the stirring rate of the solution on electrochemical processes was studied, the cyclic voltamogramms are shown in Figure 5.

As can be seen from the obtained polarization curves, there is an increase in the currents of reduction and oxidation of thallium with an increase in stirring rate of the electrolyte. In this case, there is a linear dependence of the current density in the anode and cathode processes on the square root of the stirring rate, which indicates the diffusion mode of the cathodic and anodic processes with the participation of thallium.

After repeated electrolysis using this method, cathode thallium was obtained with a purity of $99.96 \%(\mathrm{TI}, \%=99.96, \mathrm{Cd}, \%=0.03, \mathrm{Cu}, \%=0.01)$. 


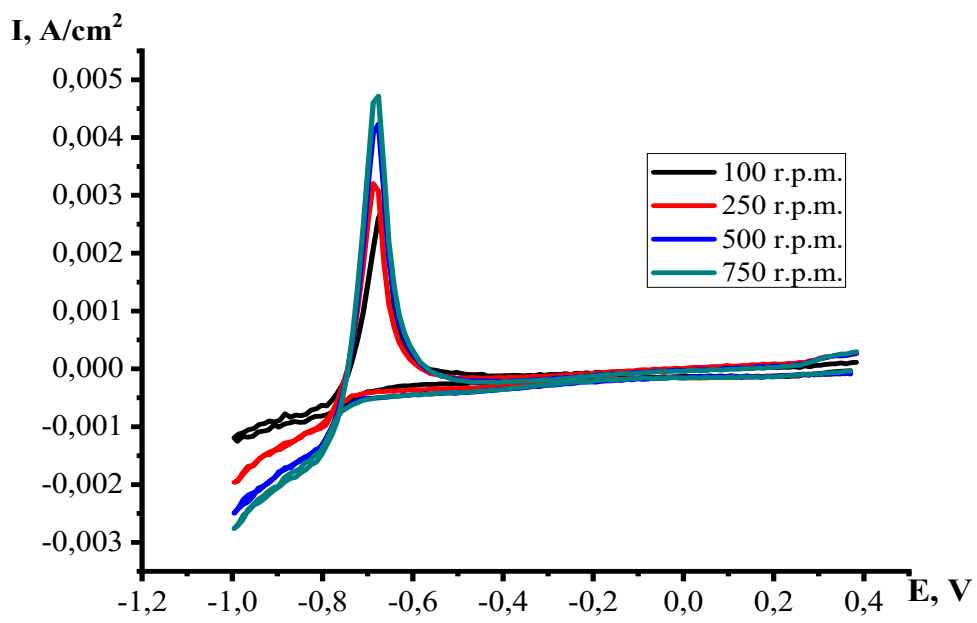

Figure 5. Polarization curves of $10^{-2} \mathrm{M} \mathrm{Tl}_{2} \mathrm{SO}_{4}$ on glassy carbon electrode at different stirring rates. Experimental conditions: scan rates, $20 \mathrm{mV}{ }^{*} \mathrm{~s}-1$; starting potential $0.3 \mathrm{~V}, \mathrm{pH}=2$.

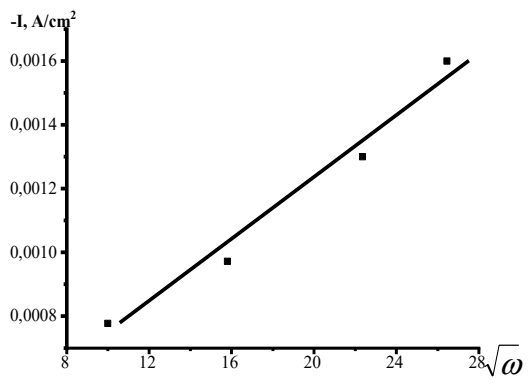

a)

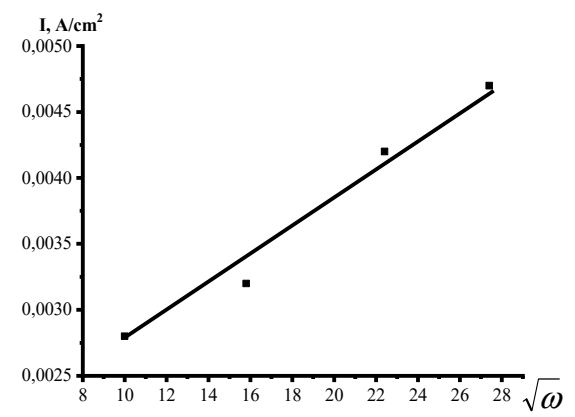

b)

Figure 6. The dependence of the catodic (a) and anodic (B) peak current densities on $\sqrt{ } \omega$, where $\omega$ is the stirring rate of solution. Experimental conditions: see Fig 5 .

Based on the obtained experimental data, the following scheme for obtaining pure thallium is proposed: 


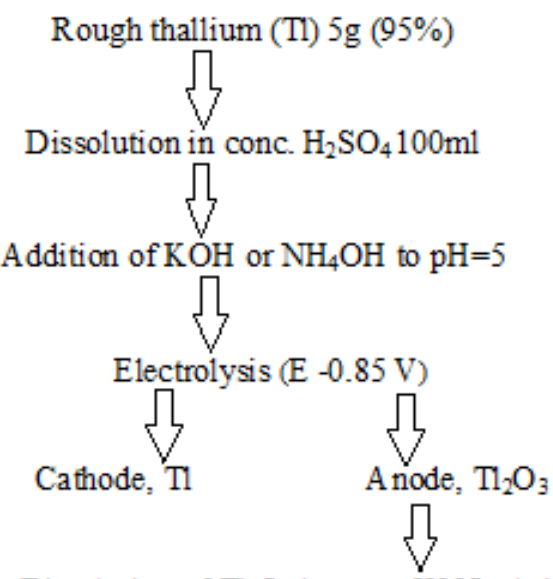

Dissolution of $\mathrm{Tl}_{2} \mathrm{O}_{3}$ in conc. $\mathrm{HNO}_{3}$, bringing to $\mathrm{pH}=5$,

addition of $10 \mathrm{ml}$ of $10^{-2} \mathrm{~mol} \mathrm{~L}^{-1} \mathrm{NH}_{4} \mathrm{SCN}$, addition $10 \mathrm{ml}$ of a solution containing

$0.0001 \mathrm{~g}$ of wood glue and $0.0002 \mathrm{~g}$ of gelatin<smiles>C1=C2CC3CC(C1)C(C2)C3</smiles>

Repeated electrolysis ( $\mathrm{E}-0.85 \mathrm{~V})$

Rotational speed of the stirrer $750 \mathrm{rpm}$<smiles>C1=CC2CC12</smiles>

Tl deposition at the cathode

(degree of purity $=99.96 \%$ )

Figure 7. The scheme for obtaining pure thallium with the addition of ammonium thiocyanate, wood glue and gelatin; electrolysis $\mathrm{pH}=2$.

Thus, it was found that the addition of hydroxylamine to restore to monovalent state of thallium, after the dissolution of thallium oxide in nitric acid, and the purity of thallium is significantly increased. For this purpose, platinum anode material was also replaced with glassy carbon material to reduce the economic costs of production.

\section{CONCLUSIONS}

Thus, the best results showed that the addition of thiocyanate, after the dissolution of thallium oxide in nitric acid contributes to the inhibition of the re-formation of thallium oxide at the anode, oxidation of trivalent thallium to monovalent and production of thallium with a purity of $99.96 \%$, due to the disposal of iron impurities. 


\section{EXPERIMENTAL}

In this paper, the measurements were carried out with a computer interfaced AUTOLAB-30 potentiostat-galvanostat. Glassy carbon electrode was used as a working electrode (GC, surface area $1 \mathrm{~cm}^{2}$ ). The auxiliary electrode was a platinum electrode (surface area $1 \mathrm{~cm}^{2}$ ), a silver chloride electrode $(\mathrm{Ag} / \mathrm{AgCl}, \mathrm{KCl} 3 \mathrm{M})$ served as reference electrode $(\mathrm{E}=-0.222 \mathrm{~V})$. In addition, hydroxylamine solution, $10^{-2} \mathrm{~mol} \mathrm{~L}^{-1}$ was used as a reducing agent, ammonium thiocyanate solution, $10^{-2} \mathrm{~mol} \mathrm{~L}^{-1}$ - as a complexing agent, wood glue (synthetic wood glue - a condensation product of urea with formaldehyde in an alkaline and acidic environment (urea-formaldehyde resin MP-RHK)) and gelatin (food grade) were used to improve the quality of the cathode precipitate. In order to dissolve the obtained thallium (III) oxide and to precipitate lead ions, $63 \% \mathrm{HNO}_{3}$ and $93.6 \% \mathrm{H}_{2} \mathrm{SO}_{4}$ (CP grade) were used, respectively. Sulfate electrolyte $\left(\mathrm{Tl}_{2} \mathrm{SO}_{4}, \mathrm{CP}\right.$ grade) and aqueous solution salts of lead, copper, cadmium and iron $\left(\mathrm{PbSO}_{4}, \mathrm{CuSO}_{4}, \mathrm{CdSO}_{4}, \mathrm{FeSO}_{4}, \mathrm{CP}\right.$ grade) were used as the test electrolyte.

Qualitative and quantitative analysis of impurities of cathode and anode sediments was carried out by atomic emission spectroscopy (Perkin Elmer, 5ICP OES 8000, Germany).

\section{REFERENCES}

1. S.S. Korovina Rare and Scattered elements. Chemistry and technology. V. 1. M: MISiS, 1996, pp 375.

2. A.N. Zelikman, B.G. Korshunov Metallurgy of rare metals: textbook for high school. $-2^{\text {nd }}$ edition, 1991, pp 432.

3. S.V. Kharitonov, V.I. Zarembo, J. Anal. Chem., 2005, 60(11), 1187-1192.

4. C. Somayye, M.A. Taher, H. Fazelirad, Microchim Acta, 2013, 11-12, 11571163.

5. A. De Leenheer, H. Nelis, W. Lambert, Encyclopedia of Analytical Science. A. Townshend (ed.). 1995, 9, pp 560.

6. T.A. Kuketaev, Khabarshy, Herald, 2008, 69.

7. B.S. Sheiman, Emergency medicine. 2014, 4, 52-57.

8. S. Moeschlin, Clin. Toxicol. 1980, 17, 133-146.

9. F. Kemper, H. Bertram, Thallium. Metall of Their Compound, Germany, Muenster, 1991, pp 1271-1241.

10. J.O. Nriagu (Ed.) Thallium in the Environment, Advances in Environmental Science and Technology, NY: Wiley and Sons, 1998, 29, pp 284. 
11. http://metal-archive.ru/metallurgiya-chistyh-metallov/2251-polucheniechistogo-talliya.html

12. B.B. Damaskin, O.A. Petry, G.A. Zirlina, Electrochemistry, 2 ed., edited and added, M.: Chemistry, Kolos, 2006, pp 672.

13. A.P. Kurbatov, G.A. Seilkhanova, M.K. Nauryzbaev, Ye. Zh. Ussipbekova, A. V. Berezovskiy, Innovative patent for invention № 29953 Electrolytic method for producing pure thallium, published 15.06. Bulletin №6. 2015.

14. G.A. Seilkhanova, A.P. Kurbatov, M.K. Nauryzbaev, A.V. Berezovskiy, A.A. Utesheva, Utility patent model № 1514 Electrochemical methods of obtaining pure thallium, published 30.06. Bulletin - № 6b. 2016;

15. G.A. Seilkhanova, Ye. Zh. Ussipbekova, A.P. Kurbatov, M.K. Nauryzbaev, A.V. Berezovskiy, A.A. Utesheva KZ. Utility patent model № 2286 Electrolytic method for producing rough thallium, published 31.07. Bulletin - № 14. 2017;

16. G.A. Seilkhanova, Ch. Jeyabhrathi, F. Scholz, A.P. Kurbatov, M.K. Nauryzbaev, A. Berezovskiy, I. J. Anal. Chem. 2015, Article ID 357514 , doi: $10.1155 / 2015 / 357514$.

17. G.A. Seilkhanova, A.P. Kurbatov, A.V. Berezovskiy, M.K, Nayryzbaev, Studia UBB Chemia, 2017, 62 4(II), 421-432.

18. G.A. Seilkhanova, Ye. Zh. Ussipbekova, A.P. Kurbatov, A.V. Berezovskiy, Bulletin of Al-Farabi Kazakh National University. Chemical series, 2014, 2 (74), 47-52.

19. S.Y. Vasiliev, Anode electrocrystallization in thallium-oxide system // Abstract. diss. Moscow, 1996, 25-32.

20. Ye. Zh. Ussipbekova, G.A. Seilkhanova, F. Scholz, A.P. Kurbatov, A.V. Berezovskiy, B.S. Bakirova, M.K. Nauryzbaev, News NAN RK. Chemical series, 2014, 5(408), 53-58.

21. V.V. Eremin, S.I. Kargov, I.A. Uspenskaya, N.E. Kuzmenko, V.V. Lunin, The basis of physical chemistry, Theory and problems, M.: Exam, 2005, pp 480

22. N. L. Glinka General Chemistry. 30 ed., 2003, pp 728.

23. L.F. Kozin, Kiev Sciences, 1983, 37.

24. https://ohranatruda.ru/ot_biblio/norma/386456/ (Russian language)

25. http://www.textreferat.com/referat-1569.html (Russian language)

26. G.A. Tsirlina, Electrochemistry, 1995, 31, 219-221. 
